\title{
TITLE:
}

\section{QUESTIONS CONCERNING THE DIAGNOSES OF SOME ASCIDIAN GENERA}

$\operatorname{AUTHOR}(\mathrm{S})$ :

Tokioka, Takasi

\section{CITATION:}

Tokioka, Takasi. QUESTIONS CONCERNING THE DIAGNOSES OF SOME ASCIDIAN

GENERA. PUBLICATIONS OF THE SETO MARINE BIOLOGICAL LABORATORY 1965, 13(2): $125-129$

ISSUE DATE:

1965-08-30

URL:

http://hdl.handle.net/2433/175399

RIGHT: 


\title{
QUESTIONS CONCERNING THE DIAGNOSES OF SOME ASCIDIAN GENERA ${ }^{\text {1) }}$
}

\author{
TAKASI TOKIOKA
}

Seto Marine Biological Laboratory

\begin{abstract}
It is very possible that specialization may occur in respective parts of the body quite independently and then the degree of specialization may be quite uneven among different organs of respective forms regarded to form a certain taxon above the rank of the genus. Therefore, it is natural that there may be found some species which are included in a certain genus with much hesitation, that is defined by a limited number of significant structural characters. Practically, the generic characters can not be so numerous for a single genus, rather the fewer they are, the more simply and distinctively the genus may be distinguished. And the question concerns which of the characters are taken for the most significant, decisive characteristics of the genus under consideration. The decisive characteristic should be of natural or phylogenical significance as far as possible, although it is inevitable to take some other characters, unrecongnizable as natural in a strict sense, provisionally for convenience's sake in some cases concerning the groups including many complicatedly confused forms. The naturalness of the generic characters, itself, is then ultimately subject to individual judgment. Thus, generally the generic diagnosis may be accompanied with some criticisms. There are a considerable number of such criticisms in the taxonomy of ascidians, too. While looking through the general taxonomy of ascidians, I have come to meet two of such cases, one concerns Herdmania of the Pyuridae and the other relates to Gamaster of the Molgulidae.
\end{abstract}

The genus Herdmania was established by LAHILIE 1887 to hold a single species Cynthia momus SAVIGNY 1816; it is separable from the genus Pyura MOLINA 1782 only by its having small rod-shaped calcareous spicules covered with rings of minute appressed spines. Various members of Pyura are provided with small calcareous spicules embedded in some parts of the body, these spicules are generally smooth surfaced and often branched; their pre-

1) Contributions from the Seto Marine Biological Laboratory, No. 438.

Publ. Seto Mar. Biol. Lab., XIII (2), 125-129, $1965 . \quad$ (Article 7) 
sence or absence is, however, not recognized by previous authors to be of a taxonomic significance. Then the only significant characteristic of Herdmania is found in the shape of the spicule. Some authors, such as HARTMEYER (19091911) and Huvs (1937-40), have not recognized the generic distinction made by such a character. I think, however, Cynthia momus is remarkable in another character, too, that is the shape of the gonad which differs distinctly from that common to general members of Pyura and consists of an elongate, sinously curved ovary bordered or enclosed by small testes.

In Pyura, the gonad is typically composed of small sacs arranged zigzag along a long slender oviduct and a common sperm duct accompanying the oviduct. However, some species which have generally been treated under the genus Pyura are provided with the gonad somewhat like that of Cynthia momus. They are $P$. legumen (LEsson) and its close allies, also $P$. stubenrauchi (Michaelsen), P. setosa (Sluiter), and P. mirabilis (von Drasche, 1884) as listed by VAN NAme (1945). In these, "the gonads are of less specialized structure, no separate sacs being formed; they are elongate bodies with an axially situated oviduct and ovary, the latter divided into a series of segments or lobes which are surrounded by the small testes" (VAN NAME 1945, p. 321). This feature was already noted by ÄrNBÄck. She mentioned in the remarks concerning her Pyura echinops n. sp. (=Pyura stubenrauchi):-- "The occurrence of forms such as $P$. echinops and $P$. stubenrauchi makes it doubtful, however, whether the genus Pyura ought to be retained in the sense proposed by Hartmeyer. It seems probable that the diagnosis as given him is to be emended, or the genus Pyura should be subdivided, on following grounds: According to the earlier diagnosis of Pyura, the branchial folds number six on each side. In Pyura echinops and its allies there are four folds on either side. Apparently this difference might be bridged over, as mentioned above. In the former the gonad on each side is divided into two series of small hermaphroditic glands with the ducts between them. In the latter the gonad is elongated; the tesitis extends on its outer side, bordering the central ovary on the inner side. The vas deferens runs along the ovary. In the former the dorsal lamina consists of a series of long languets. In Pyura echinops the lamina is represented by a broad membrane with a fine serrated margin, and in $P$. stubenrauchi its posterior part is divided into short languets, the anterior part having the margin "eingekerbt".- However, the two species in question are provisionally referred to the genus Pyura. They are known in a single specimen each, a material too limited to allow of any definite change, for the present, in the classification proposed by HARTMEYER" (ÄRNB̈̈CK 1938, p. 28).

Of the features referred by these authors, the number of the branchial plications does not seem to be of taxonomical importance. Miciraelsen (1912) established the genus Pyuropsis to hold his Cynthia stubenrauchi and placed it 
in the Styelidae for the reason of its having four folds on each side of the branchial sac. Of cource, this is unacceptable as shown in previous papers, since that species is provided with the elongate stomach with a liver composed of irregular glandular folds and the numerous tentacles twice or sparingly three times pinnate; these characters, common to most* members of the families Pyuridae and Molgulidae, but not shared by the Styelidae and Botryllidae, are evidently regarded as more fundamental than the number of the banchial folds. Contrarily, the structure of the gonad seems to be of great importance in the Pyuridae as in the Styelidae. I agree with the thought of $\ddot{A}_{\mathrm{RNBÄCK}}$ and VAN NAME to separate $P$. legumen, $P$. stubenrauchi, P. setosa and $P$. mirabilis from other members of Pyura in this respect. Probably these species may belong to the group including Herdmania, Boltenia, Culeolus and presumably Halocynthia and Microcosmus, too, all having the compact gonad, undivided into sacs; though the distinction by the structure of the gonad is not of the absolute distinctiveness as a possible intermediate state may be seen in some species such as Pyura antillarum VAN NAME, in which the gonad is an elongate body divided into irregularly shaped segments by transverse constrictions. The transverse direction of the stigmata in Boltenia can not be of great phylogenical importance as this feature also occurs in other families independently.

I don't mean that all these species mentioned above form together a special group. In Pyura legumen, Pyura stubenrauchi and Pyura setosa the dorsal lamina is more or less membranous rather than be a series of languets, although it is serated along the edge ( $P$. legumen) or partially composed of small languets ( $P$. stubenrauchi). This feature, together with the structure of the gonad, seems to place these species near Microcosmus. The membranous appearance of the dorsal lamina alone may be insufficient for this treatment, as a feature somewhat like this is seen in Pyura haustor (STimpson), too, whose gonad is of the typical structure for Pyura. On the other hand, Pyura mirabilis is related most closely to Cynthia momus. The only significant difference between these two forms is the presence of the calcareous spicules of a special structure in C.momus. It is not impossible that the close resemblance in the structure of the gonad is much more natural than the presence or absence of spicules. In this sense, VAN NAME was correct in placing $P$. mirabilis just before Herdmania in his monograph of 1945 . In order to include $P$. mirabilis within it, the diagnosis of the genus Herdmania may be emended as follows: a genus of the Pyuridae, with the dorsal lamina composed of a series of languets and the gonad undivided into two series of small hermaphroditic glands with the ducts between them; the animal is not pedun-

\footnotetext{
* Tentacles are simple in Heterostigma.
} 
culated.

The genus Gamaster was first defined by Pizon (1896), to hold his $G$. dakarensis, as follows: the molgulid with the branchial sac and the alimentary organ of the same structures as in Eugyra, but with the gonad solely on the right body side, which is unique in structure; the ovary and the tests are distinctly separated from each other, the ovary is an elongate curved sac starting approximately the centre of the right side of the body and opening in the anterior part of the cloacal cavity, while the male gonad assumes roughly a roundish disc covering the most part of the right body side just in front of the starting point of the ovary and consisting of a large number of completely separate elongate testes radially arranged. Each testis is branched in the periphery and opens to the right peribranchial cavity at the end at the centre of the male gonad. The generic name Gamaster was given to the species by Pizon because of this stellate structure of the male gonad, which must be regarded by this author as the most striking. Nevertheless this important generic character has been neglected by successive authors (HARTMEYer 1909-1911, p. 1319 ; OKA* 1934 ; HuUs* 1940, pp. 677-678) who have emphasized only the presence of a single gonad on the right body side, although HARTMEYER still referred that the testes and the ovary are separated completely from each other. Only SeEliger (1893-1907, pp. 1195-1196) reproduced the diagnosis given by PIzon very faithfully. OKa (1934) found a new eugyrid ascidian, Gamaster japonicus, from the Japanese waters, which has a single gonad on the right body side only. Although the structure of the gonad of this form resembles precisely that of Eugyra glutinans (MOELLER) and completely differs from that of Gamaster dakarensis, OKA placed this form under the genus Gamaster because of the presence of the gonad on the right body side only. I have followed OKA without feeling any questions. Now, however, being aware of the taxonomical importance of the structure of the gonad in respective ascidian families, I have come to pay attention to the treatment of my Eugyra (Eugyrioides) hexarhiza which has the gonad just like that of Gamaster dakarensis on either side (1949; P1. 6, figs. 2 and 3). So far as $I$ am aware, this is the second eugyrid having the gonad of the gamastertype. I think it more reasonable to treat G. dakarensis and Eugyrioides hexarhiza together under the same genus, Gamaster, whose diagnosis is now to be emended as follows: The eugyrid in which the ovary and testes are completely separated from each other, the testes are elongate bodies, gathered radially near the starting point of the ovary in a stellate arrangement, each opening

* OKA and HuUs are of the opinion to subdivide the genus Eugyra into three subgenera Eugyra s. s., Eugyrioides and Gamaster. 
at the centre of the disc-shaped male gonad and branched in the periphery. Then, OKA's Gamaster japonicus should be removed from the genus Gamaster and treated together with Eugyra glutinans (MOELLER). I agree the opinion of Michaelsen (1915, pp. 339-343), Hartmeyer (1923) and Van Name (1945, p. 433), that the presence of gonad on one or both sides of the body cannot be a generic or subgeneric characteristic and thus the genus Eugyrioides SEELIGER is to be included within Eugyra. The validity of the genus (or the subgenus of Eugyra) Gamaster is then judged differently according to the subjective point of view of respective students.

\section{REFERENCES}

ÄrnbÄCK-CHristie-Linde, A. (1938): Ascidiacea. Part 1. Further Zoological Results of the Swedish Antarctic Expedition 1901-1903, 54 pp., 4 pls., 11 text-figs.

HARTMEYER, R. (1909-1911): Ascidien in BRONN's Klassen und Ordnungen des Tier-reichs, Vol. 3, Suppl., pp. 1281-1773.

Huus, J. (1937-1940): Tunicata in KÜkenthal \& KRumbach's Handbuch der Zoologie, Vol. 5, Part 2.

Michaelsen, W. (1915): Tunicata in Beiträge zur Kenntnis der Meeresfauna Westafrikas, Vol. I, pp. 319-518, PIs. 16-19.

OKA, A. (1934): Eine zweite Gamaster-Art (Ascidiae Simplices). Proc. Imp. Acad. Tokyo, Vol. 10, No. 9, pp. 594-596, 1 text-fig.

SeEliger, O. (1893-1907): Tunicata in BronN's Klassen und Ordnungen des Tier-reichs, Vol. 3, Suppl., 1280 pp.

TokiokA, T. (1949): Contributions to the Japanese ascidian fauna. I. Ascidans collected by Prof. Mryadi and Mr. MAsui during the bottom survey 1939-40. Publ. Seto Mar. Biol. Lab., Vol. 1, No, 1, pp. 1-17, 7 pls.

VAn Name, W. G. (1945): The North and South American ascidians, Bull. American Mus. Nat. Hist., Vol. 84 . 